\title{
FAKTOR-FAKTOR YANG BERHUBUNGAN DENGAN KEEFEKTIFAN DAN KEEFISIENAN ADMINISTRASI PELAYANAN PADA PASIEN RAWAT JALAN
}

\author{
Citra Amelia Oktaviani*, Mpkh.Firman Ismana**, Suzana Indragiri***
}

\begin{abstract}
ABSTRAK
Keefektifan adalah melakukan pekerjaan yang benar dan sesuai dengan cara yang tepat untuk mencapai suatu tujuan yang telah direncanakan, sedangkan keefisienan adalah hasil dari usaha yang telah dicapai lebih besar dari usaha yang dilakukan. Penelitian ini bertujuan untuk mengetahui faktor-faktor yang berhubungan dengan keefektifan dan keefisienan administrasi pelayanan pada pasien di instalasi rawat jalan rumah sakit sumber kasih kota Cirebon tahun 2014. Metode yang digunakan pada penelitian ini adalah deskriptif analitik dengan menggunakan desain penelitian cross sectional. Hal yang ingin di teliti adalah faktor-faktor yang berhubungan dengan keefektifan dan keefisienan administrasi pelayanan diantaranya ketepatan waktu, sarana dan prasarana, sistem komputerisasi, dan sumber daya manusia terhadap keefektifan dan keefisienan administrasi pelayanan pada pasien di instalasi rawat jalan rumah sakit sumber kasih kota Cirebon tahun 2014. Pengumpulan data dilakukan dengan wawancara menggunakan kuesioner. Pengolahan dan analisa data dilakukan dengan menggunakan program SPSS (Statistic Package For Social Science). Populasi penelitian ini adalah pasien rawat jalan yang berkunjung ke rumah sakit sumber kasih pada bulan januari sampai desember tahun 2013, yaitu sebanyak 947 pasien, dengan pengambilan sampel ditentukan dengan cara Consecutive Sampling yaitu pengambilan sampel ditentukan berdasarkan urutan datangnya pasien, sebanyak 90 pasien. Didapatkan dari hasil penelitian, pasien yang mempuyai keefektifan dan keefisienan yang efektif dan efisien sebanyak $34,4 \%$ dan $65,6 \%$ pasien yang mempunyai keefektifan dan keefisienan yang tidak efektif dan efisien. Hasil uji statistic (uji chi square) diperoleh bahwa ada hubungan yeng bermakna antara ketepatan waktu dengan keefektifan dan keefisienan administrasi pelayanan $(p$-value $=0,002)$, ada hubungan yeng bermakna antara sarana dan prasarana dengan keefektifan dan keefisienan administrasi pelayanan ( $p$-value $=0,017$ ), ada hubungan yeng bermakna antara sistem komputerisasi dengan keefektifan dan keefisienan administrasi pelayanan ( $p$-value $=0,011)$, ada hubungan yeng bermakna antara sumber daya manusia dengan keefektifan dan keefisienan administrasi pelayanan ( $p$-value $=$ $0,000)$.
\end{abstract}

Kata Kunci : Keefektifan dan keefisienan administrasi pelayanan.

\begin{abstract}
Effectiveness is doing the job properly and in accordance with the proper way to achieve a goal that has been planned, while efficiency is the result of the effort that has been achieved is greater than the work done.This study to determine the factors related to the effectiveness and efficiency of administrative services to patients in hospital outpatient installation source love Cirebon city in 2014. The method used in this research is descriptive analytical cross-sectional research design. Things to be investigated are the factors related to the effectiveness and efficiency of administrative services including timeliness, facilities and infrastructure, computerized systems, and human resources administration of the effectiveness and efficiency of care for patients in hospital outpatient installation source Cirebon city of love year 2014.The data was collected using a questionnaire interview. Processing and data analysis were performed using the SPSS (Statistics Package For Social Science ) version 18. The study population was patients who visited the outpatient hospital source of love in the month of January to December in 2013, as many as 947 patients, with a sampling determined by sampling Consecutive sampling is determined by the order of arrival of the patient, as many as 90 patients. Obtained from the results of the study, patients who mempuyai effectiveness and efficiency of effective and efficient as much as $34.4 \%$ and $65.6 \%$ of patients who have the effectiveness and efficiency are not effective and efficient . The results of statistical tests (chi square test) found that there is a significant relationship between timeliness GCC with administrative effectiveness and efficiency of care $(p-$ value $=0.002)$, there was a significant relationship between the GCC infrastructure to the effectiveness and efficiency of administrative services $(p-$ value $=0.017)$, there was a significant relationship between the GCC with a computerized system effectiveness and efficiency of administrative services $(p-$ value $=0.011)$, no significant relationship between the GCC human resources administration with the effectiveness and efficiency of care $(p-$ value $=0.000)$.
\end{abstract}

Keywords : Administrative effectiveness and efficiency of service

* Alumni PSKM STIKes Cirebon Lulus Tahun 2014

** Staf Pengajar Program Studi S1 Kesehatan Masyarakat STIKes Cirebon

*** Staf Pengajar Program Studi S1 Kesehatan Masyarakat STIKes Cirebon 


\section{PENDAHULUAN}

Perkembangan dunia kesehatan dewasa ini semakin pesat, dengan kemajuan ilmu pengetahuan dan teknologi di saat ini menambah kualitas ketenaga kerjaan terutama di bidang pelayanan Rumah Sakit.Rumah Sakit merupakan pusat pelayanan yang menyelenggarakan pelayanan medik dasar dan medik spesialistik, pelayanan penunjang medis, pelayanan perawatan, baik rawat jalan, rawat inap maupun pelayanan instalasi. Rumah sakit sebagai salah satu sarana kesehatan dapat diselenggarakan oleh pemerintah, dan atau masyarakat. ${ }^{1}$

Pelayanan kesehatan merupakan salah satu upaya untuk dapat memenuhi kebutuhan serta tuntutan masyarakat terhadap kesehatan yang dipandang mempunyai peranan yang sangat penting pada masa krisis yang sedang terjadi sampai sekarang, dan dibutuhkan proses pengadministrasian dalam melaksanakan pelayanan kesehatan tersebut. Pelayanan kesehatan itu sendiri meliputi pelayanan medik, pelayanan penunjang medik, rehabilitasi medic dan pelayanan asuhan keperawatan. Pelayanan tersebut dilaksanakan melalui unit gawat darurat, unit rawat jalan dan unit rawat inap. $^{2}$

Pelayanan rawat jalan adalah salah satu unit kerja di lingkup rumah sakit yang melayani pasien berobat jalan dan tidak lebih dari 24 jam pelayanan, termasuk seluruh prosedur diagnostik dan terapeutik. Pelayanan rawat jalan di Rumah Sakit terdiri dari beberapa macam departemen atau sub bagian di dalamnya yaitu Unit Gawat Darurat (UGD), Laboratorium, Apotek Rawat Jalan, dan Radiologi. ${ }^{3}$

Salah satu jenis pelayanan penunjang medik di rumah sakit adalah pelayanan radiologi yang dilakukan oleh sebuah unit instalasi radiologi. Instalasi radiologi adalah tempat penyelenggaraan pelayanan radiologi dan atau kepada pasien yang membutuhkan dengan menegakkan diagnosis yang cepat dan tepat dan atau pelaksanaan pemeriksaan tindakan khusus yang akurat. Banyak bagian radiologi yang menjadi lambang kebanggaan tiap-tiap rumah sakit, karena layanan diagnostik berteknologi tinggi yang merupakan alat pemasaran yang efektif dalam menarik para dokter atau pasien dan prosedur di instalasi radiologi merupakan sumber pendapatan yang besar. ${ }^{4}$

Jenis Pelayanan Radiologi di Rumah Sakit Sumber Kasih Kota Cirebon meliputi Foto Rontgen dan Ultra Sonografi (USG) dengan peralatan pendukung seperti Radiologi Konvensional, Mammograph X-Ray, USG, Aprone, Film Badge, dan lain-lain. Perlu disadari bahwa adanya pelayanan Radiologi tersebut, dibutuhkan tata cara pelaksanaan administrasi yang sesuai dengan Standar Operasional Prosedur (SOP) yang ada.

Administrasi pelayanan Radiologi di Instalasi Radiologi pada pasien rawat jalan Rumah Sakit Sumber Kasih Kota Cirebon merupakan suatu proses pencatatan dan pelaporan kegiatan pelayanan radiologi dari tahap awal pendaftaran pasien rawat jalan sampai dengan di loket pembayaran atau kasir.

Seiring dengan meningkatnya permintaan layanan kesehatan dan semakin banyak munculnya rumah sakit, maka Rumah Sakit Sumber Kasih Kota Cirebon harus dapat beroperasi secara efektif dan efisien agar dapat bersaing dengan Rumah Sakit lainnya. Maka dari itu di dalamnya pun tidak lepas dari adanya faktor-faktor yang menentukan keefektifan dan keefisienan administrasi pelayanan di Rumah Sakit khususnya di bagian Instalasi Radiologi, dengan alasan agar terciptanya Rumah Sakit yang mempunyai standar dan terakreditasi dengan baik.

Banyak kendala yang terjadi dari pengelolaan Rumah Sakit yang menyebabkan pasien tidak dapat mengikuti aturan atau prosedur dan tata cara untuk pelaksanaan pemeriksaan di Instalasi Radiologi yang menyebabkan pengadministrasian menjadi terhambat dan mengulur waktu, serta munculnya masalah mengenai pasien yang tidak dapat membayar atau biaya yang pada saat itu dikenakan oleh pasien jadi tidak bisa dibayar oleh pasien, dikarenakan pasien tidak mengetahui denah/lokasi tempat kasir yang berada di lantai 1 tersebut, alur pelayanan administrasi, prosedur pelayanan adminisrasinya serta dari sumber daya manusianya itu sendiri seperti petugas yang terkait di dalamnya.

Di Rumah Sakit Sumber Kasih Kota Cirebon dilihat dari hasil bulan Januari sampai dengan Desember Tahun 2013 diketahui ada10 pasien yang tidak melakukan pembayaran di Kasir setelah 
pemeriksaan penunjang seperti pelayanan Radiologi di Instalasi Radiologi Rumah Sakit Sumber Kasih Kota Cirebon dikarenakan adanya berbagai faktor-faktor yang memungkinkan ketidakefektifan dan ketidakefisienan dalam administrasi pelayanan kesehatan.

Oleh karena itu penulis tertarik mengambil judul skripsi "Faktor-faktor yang menentukan keefektifan dan keefisienan administrasi pelayanan pada pasien rawat jalan di Instalasi Radiologi Rumah Sakit Sumber Kasih Kota Cirebon Tahun 2014". Tujuan penelitian adalah mengetahui faktor-faktor yang berhubungan keefektifan dan keefisienan administrasi pelayanan pada pasien rawat jalan di Instalasi Radiologi Rumah Sakit Sumber Kasih Kota Cirebon Tahun 2014.

\section{METODOLOGI PENELITIAN}

Dalam penelitian ini penulis menggunakan metode rancangan deskriptif analitik. Yaitu menggambarkan antara variabel bebas dan variabel terikat dengan dianalisa dan diuji kebenarannya. Pendekatan Cross Sectional yang artinya rancangan penelitian dengan melakukan pengukuran atau pengamatan pada saat bersamaan (sekali waktu) antara faktor risiko/paparan dengan penyakit. ${ }^{5}$

Populasi dalam penelitian ini adalah seluruh pasien rawat jalan yang berkunjung ke Rumah Sakit Sumber Kasih padabulan Januari sampai dengan Desember pada Tahun 2013 sejumlah 947 pasien. Pengambilan sampel ditentukan dengan cara Consecutive Sampling yaitu pengambilan sampel ditentukan berdasarkan urutan datangnya pasien. ${ }^{6}$ Pengumpulan data dilakukan dengan wawancara menggunakan kuesioner sedangkan untuk pengujian hipotesis dengan menggunakan uji chi-square

\section{HASIL PENELITIAN \\ Ketepatan waktu}

Hasil penelitian menunjukkan bahwa $65,6 \%$ responden menyatakan ketepatan waktu yang tepat sedangkan $34,4 \%$ responden menyatakan ketepatan waktu yang tidak tepat terhadap keefektifan dan keefisienan administrasi pelayanan.

\section{Sarana dan prasarana}

Hasil penelitian menunjukkan bahwa $62,2 \%$ responden menyatakan sarana dan prasarana yang baik sedangkan $37,8 \%$ responden menyatakan sarana dan prasarana yang kurang baik terhadap keefektifan dan keefisienan administrasi pelayanan.

\section{Sistem komputerisasi}

Hasil penelitian menunjukkan bahwa $61,1 \%$ responden menyatakan sistem komputerisasi yang baik sedangkan 38,9\% responden menyatakan sistem komputerisasi yang kurang baik terhadap keefektifan dan keefisienan administrasi pelayanan.

\section{Sumber daya manusia}

Hasil penelitian menunjukkan, responden yang menyatakan bahwa sumber daya manusia baik sebesar $68,9 \%$ dan $31,1 \%$ menyatakan kurang baik terhadap keefektifan dan keefisienan administrasi pelayanan.

\section{Kefektifan dan keefisienan}

Hasil penelitian menunjukkan, responden yang menyatakan bahwa keefektifan dan keefisienan administrasi pelayanan baik sebesar $65,6 \%$ dan $34,4 \%$ menyatakan tidak efektif dan efisien. 


\section{Hubungan ketepatan waktu dengan keefektifan dan keefisienan administrasi pelayanan}

Tabel 1 Hubungan ketepatan waktu dengan keefektifan dan keefisienan administrasi pelayanan

\begin{tabular}{|c|c|c|c|c|c|c|c|}
\hline \multirow{3}{*}{ Ketepatan waktu } & \multicolumn{4}{|c|}{$\begin{array}{c}\text { Keefektifan dan keefisienan administrasi } \\
\text { pelayanan }\end{array}$} & \multirow{2}{*}{\multicolumn{2}{|c|}{ Total }} & \multirow{2}{*}{$\mathrm{P}$ value } \\
\hline & \multicolumn{2}{|c|}{$\begin{array}{c}\text { Tidak efektif dan } \\
\text { efisien }\end{array}$} & \multicolumn{2}{|c|}{ Efektif dan efisien } & & & \\
\hline & $\mathrm{n}$ & $\%$ & $\mathrm{n}$ & $\%$ & $\mathrm{n}$ & $\%$ & \multirow{4}{*}{0,002} \\
\hline Tidak Tepat & 4 & 12,9 & 27 & 87,1 & 31 & 100 & \\
\hline Tepat & 27 & 45,8 & 32 & 54,2 & 59 & 100 & \\
\hline Total & 31 & 34,4 & 59 & 65,6 & 90 & 100 & \\
\hline
\end{tabular}

Dari hasil statistik diperoleh $\mathrm{P}=0,002(\mathrm{p} \leq \alpha)$ yang menunjukkan ada hubungan antara ketepatan waktu dengan keefektifan dan keefisienan administrasi pelayanan di Instalasi Radiologi Rumah Sakit Sumber Kasih Kota Cirebon Tahun 2014.

\section{Hubungan sarana dan prasarana dengan keefektifan dan keefisienan administrasi pelayanan}

Tabel 2 Hubungan sarana dan prasarana dengan keefektifan dan keefisienan administrasi pelayanan.

\begin{tabular}{|c|c|c|c|c|c|c|c|}
\hline \multirow{3}{*}{ Sarana dan prasarana } & \multicolumn{4}{|c|}{$\begin{array}{c}\text { Keefektifan dan keefisienan administrasi } \\
\text { pelayanan }\end{array}$} & \multirow{2}{*}{\multicolumn{2}{|c|}{ Total }} & \multirow[t]{2}{*}{$\mathrm{P}$ value } \\
\hline & \multicolumn{2}{|c|}{ Tidak efektif dan efisien } & \multicolumn{2}{|c|}{ Efektif dan efisien } & & & \\
\hline & $\mathrm{n}$ & $\%$ & $\mathrm{n}$ & $\%$ & $\mathrm{n}$ & $\%$ & \multirow{4}{*}{0,017} \\
\hline Kurang baik & 6 & 17,6 & 28 & 82,4 & 34 & 100 & \\
\hline Baik & 25 & 44,6 & 31 & 55,4 & 56 & 100 & \\
\hline Total & 31 & 34,4 & 59 & 65,6 & 90 & 100 & \\
\hline
\end{tabular}

Dari hasil statistik diperoleh hasil $\mathrm{P}=0,017(\mathrm{p} \leq \alpha)$ yang menunjukkan ada hubungan antara sarana dan prasarana dengan keefektifan dan keefisienan administrasi pelayanan di Instalasi Radiologi Rumah Sakit Sumber Kasih Kota Cirebon Tahun 2014.

\section{Hubungan sistem komputerisasi dengan keefektifan dan keefisienan administrasi pelayanan}

Tabel 3 Hubungan sistem komputerisasi dengan keefektifan dan keefisienan administrasi pelayanan

\begin{tabular}{|c|c|c|c|c|c|c|c|}
\hline \multirow{3}{*}{ Sistem komputerisasi } & \multicolumn{4}{|c|}{$\begin{array}{l}\text { Keefektifan dan keefisienan administrasi } \\
\text { pelayanan }\end{array}$} & \multirow{2}{*}{\multicolumn{2}{|c|}{ Total }} & \multirow{2}{*}{$\mathrm{P}$ value } \\
\hline & \multicolumn{2}{|c|}{$\begin{array}{c}\text { Tidak efektif dan } \\
\text { efisien }\end{array}$} & \multicolumn{2}{|c|}{ Efektif dan efisien } & & & \\
\hline & $\mathrm{n}$ & $\%$ & $\mathrm{n}$ & $\%$ & $\mathrm{n}$ & $\%$ & \multirow{4}{*}{0,011} \\
\hline Kurang baik & 6 & 17,1 & 29 & 82,9 & 35 & 100 & \\
\hline Baik & 25 & 45,5 & 30 & 54,5 & 55 & 100 & \\
\hline Total & 31 & 34,4 & 59 & 65,6 & 90 & 100 & \\
\hline
\end{tabular}

Dari hasil statistik diperoleh hasil $\mathrm{P}=0,011(\mathrm{p} \leq \alpha)$ yang menunjukkan ada hubungan antara sistem komputerisasi dengan keefektifan dan keefisienan administrasi pelayanan di Instalasi Radiologi Rumah Sakit Sumber Kasih Kota Cirebon Tahun 2014. 


\section{Hubungan sumber daya manusia dengan keefektifan dan keefisienan administrasi pelayanan}

Tabel 4 Hubungan sumber daya manusia dengan keefektifan dan keefisienan administrasi pelayanan.

\begin{tabular}{|c|c|c|c|c|c|c|c|}
\hline \multirow{3}{*}{ Sumber daya manusia } & \multicolumn{4}{|c|}{$\begin{array}{l}\text { Keefektifan dan keefisienan administrasi } \\
\text { pelayanan }\end{array}$} & \multirow{2}{*}{\multicolumn{2}{|c|}{ Total }} & \multirow{2}{*}{$\mathrm{P}$ value } \\
\hline & \multicolumn{2}{|c|}{$\begin{array}{l}\text { Tidak efektif dan } \\
\text { efisien }\end{array}$} & \multicolumn{2}{|c|}{ Efektif dan efisien } & & & \\
\hline & $\mathrm{n}$ & $\%$ & $\mathrm{n}$ & $\%$ & $\mathrm{n}$ & $\%$ & \multirow{4}{*}{0,000} \\
\hline Kurang baik & 2 & 7,1 & 26 & 92,9 & 28 & 100 & \\
\hline Baik & 29 & 46,8 & 33 & 53,2 & 62 & 100 & \\
\hline Total & 31 & 34,4 & 59 & 65,6 & 90 & 100 & \\
\hline
\end{tabular}

Dari hasil statistik diperoleh hasil $\mathrm{P}=0,000(\mathrm{p} \leq \alpha)$ yang menunjukkan ada hubungan antara sumber daya manusia dengan keefektifan dan keefisienan administrasi pelayanan di Instalasi Radiologi Rumah Sakit Sumber Kasih Kota Cirebon Tahun 2014.

\section{PEMBAHASAN}

\section{Hubungan ketepatan waktu dengan keefektifan dan keefisienan administrasi pelayanan}

Hasil penelitian menunjukkan bahwa ada hubungan yang bermakna antara hubungan ketepatan waktu dengan keefektifan dan keefisienan administrasi pelayanan. Ketepatan waktu adalah Untuk memperoleh hasil yang memuaskan, pelayanan kesehatan harus dilaksanakan dalam waktu dan cara yang tepat oleh pemberi pelayanan yang tepat dan menggunakan yang tepat serta dengan biaya yang efisien.

Dalam ketepatan waktu pasien yang tidak tepat waktu tetapi efektif dan efisien nilai prosentase lebih tinggi, dikarenakan pasien yang tidak tepat waktu datang untuk pelayanan tetapi bisa efektif dan efisien dengan cara dari pengadministrasiannya maupun pelayanan di Rumah Sakit khususnya bagian Instalasi Radiologi ini bisa cepat, cekatan, serta mudah terevaluasi dengan baik dan juga bisa tertangani oleh petugas yang terkait di dalamnya.

\section{Hubungan sarana dan prasarana dengan keefektifan dan keefisienan administrasi pelayanan}

Hasil penelitian menunjukkan bahwa ada hubungan yang bermakna antara hubungan sarana dan prasarana dengan keefektifan dan keefisienan administrasi pelayanan. Sarana dan prasarana adalah Sesuatu yang dapat digunakan sebagai angkat/peralatan dalam pencapaian maksud dan tujuan serta faktor penunjang terlaksananya suatu proses kegiatan.

Dalam sarana dan prasarana yang kurang baik tetapi efektif dan efisien nilai prosentasi lebih tinggi, dikarenakan meskipun fasilitas sarana dan prasarana kurang memadai tetapi fasilitas sarana dan prasarananya masih bisa dipergunakan dengan baik dalam administrasi maupun pelayanan pemeriksaan di bagian Instalasi Radiologinya.

\section{Hubungan sistem komputerisasi dengan keefektifan dan keefisienan administrasi pelayanan}

Hasil penelitian menunjukkan bahwa ada hubungan yang bermakna antara hubungan sistem komputerisasi dengan keefektifan dan keefisienan administrasi pelayanan. Sistem komputerisasi adalah Penggunaan komputer sebagai alat bantu dalam kegiatan pengolahan data yang dilakukan secara manual dan menggunakan komputer yang sudah di program sebelumnya, pengolahan data ini dimulai dengan perekam data hingga sampai pada pencetakan laporan.

Dalam sistem komputerisasi kurang baik tetapi efektif dan efisien nilai prosentase lebih tinggi dikarenakan, meskipun sistem komputerisasi kurang baik tetapi dari penginputan data pasien maupun pembuatan nota di sistem komputer masih bisa menjadi informasi yang baik serta mudah dalam pencarian data lengkap yang dibutuhkan oleh pasien maupun Rumah Sakit, oleh karena itu meskipun masih kurang lengkap ataupun kurang baik di dalam sistem komputerisasi tetapi masih bisa menjadi sumber informasi data Rumah Sakit dengan baik. 


\section{Hubungan sumber daya manusia dengan keefektifan dan keefisienan administrasi pelayanan}

Hasil penelitian menunjukkan bahwa ada hubungan yang bermakna antara hubungan sumber daya manusia dengan keefektifan dan keefisienan administrasi pelayanan. Sumber daya manusia adalah potensi yang terkandung dalam diri manusia untuk mewujudkan perannya sebagai makhluk sosial yang adaptif dan transformatif yang mampu mengelola dirinya sendiri serta seluruh potensi yang terkandung di alam menuju tercapainya kesejahteraan kehidupan dalam tatanan yang seimbang dan berkelanjutan.

Dalam sumber daya manusia kurang baik tetapi efektif dan efisien nilai prosentase lebih tinggi dikarenakan, meskipun sumber daya manusia di bagian Instalasi Radiologi tenaga sumber daya manusianya masih kurang, tetapi dalam pelayanan maupun administrasinya masih bisa tertangani dengan baik dan cepat.

\section{SIMPULAN}

1. Total pasien yang mempunyai ketepatan waktu yang tidak efektif dan efisien, sarana dan prasarana yang tidak efektif dan efisien, sistem komputerisasi yang tidak eektif dan efisien, serta sumber daya manusia yang tidak efektif dan efisien sebanyak 34,4\%, dan yang mempunyai ketepatan waktu yang tepat tetapi efektif dan efisien, sarana dan prasarana yang baik tetapi efektif dan efisien, sistem komputerisasi yang baik tetapi efektif dan efisien, serta sumber daya manusia yang baik tetapi efektif dan efisien sebanyak 65,6\%.

2. ada hubungan yang bermakna antara hubungan ketepatan waktu dengan keefektifan dan keefisienan administrasi pelayanan di Instalasi Radiologi Rumah Sakit Sumber Kasih Kota Cirebon Tahun 2014.

3. ada hubungan yang bermakna antara hubungan sarana dan prasarana dengan keefektifan dan keefisienan administrasi pelayanan di Instalasi Radiologi Rumah Sakit Sumber Kasih Kota Cirebon Tahun 2014.

4. ada hubungan yang bermakna antara hubungan sistem komputersasi dengan keefektifan dan keefisienan administrasi pelayanan di Instalasi Radiologi Rumah Sakit Sumber Kasih Kota Cirebon Tahun 2014.

5. ada hubungan yang bermakna antara hubungan sumber daya manusia dengan keefektifan dan keefisienan administrasi pelayanan di Instalasi Radiologi Rumah Sakit Sumber Kasih Kota Cirebon Tahun 2014.

\section{SARAN}

1. Untuk Instalasi Radologi Rumah Sakit Sumber Kasih

1) Sebaiknya untuk di bagian Administrasi pelayanan pasien rawat jalan lebih tepat waktu, cepat, dan terampil dalam pemasukan dan penginputan data pasien serta lebih teliti lagi jika sudah ada yang mendaftar dengan nama atau alamat pasien yang sama.

2) Sebaiknya untuk di bagian pendaftaran ( Customer Service ) penginputan dan pemasukan data pasien ke dalam sistem komputer lebih dipercepat lagi, untuk mengantisipasi dalam terhambatnya penginputan nota atau kwitansi yang akan dibayar oleh pasien.

3) Lebih diperhatikan lagi dalam fasilitas sarana dan prasarana yang ada di bagian Instalasi Radiologi baik di bagian Administrasi Pelayanan Radiologi maupun di dalam ruangan Instalasi Radiologinya.

4) Menambah Sumber Daya Manusia (SDM) untuk bagian Instalasi Radiologi, minimal 1 orang untuk bagian petugas Administrasi Radiologi, 3 orang untuk petugas Teknik Pemeriksaan Radiologi, dan 1 orang untuk petugas Kamar Gelap di bagian Instalasi Radiologi.

2. Untuk mahasiswa/i STIKes Cirebon

Dapat memberikan pengetahuan tentang keefektifan dan keefisienan administrasi pelayanan pada pasien rawat jalan sehingga diharapkan sebagai acuan atau landasan untuk 
meningkatkan pengetahuan bagi mahasiswa/i STIKes Cirebon khususnya program studi Kesehatan Masyarakat.

3. Untuk peneliti lain

Diharapkan dapat menerapkan mata kuliah metodologi penelitian dan menambah pengalaman dalam penulisan skripsi, serta sebagai masukan pengetahuan tentang proses administrasi yang berjalan dalam pelayanan pasien rawat jalan di bagian Instalasi Radiologi.

\section{DAFTAR PUSTAKA}

1. Depkes RI. Pengertian rumah sakit; [ diakses tanggal 26 September 2013] Diunduh dari: http://google.com/ pengertian rumah sakit menurut Depkes RI.; 1994

2. Rudolf. 003. pengertian pelayanan kesehatan; [di akses tanggal 15 September 2013] di unduh dari :http://café - radiologi. blogspot. Com/2011/10 / standar - operational - prosedure sop. Html /pengertian pelayanan kesehatan.

3. Simon. Pengertian pelayanan rawat jalan; [di unduh tanggal 17 September 2013] tersedia dari : http: //google. com/cafe radiology/ pengertian pelayanan rawat jalan; 1983.

4. Callinston. Pelayanan penunjang medik; [di akses tanggal 19 September 2013] diunduh dari: http://google. com/ cafe radiology/ pelayanan penunjang medik.;1977.

5. Dr. Soekidjo Notoatmodjo, Metodologi penelitian kesehatan - Edisi Revisi. Jakarta: Rineka Cipta cetakan kedua; Januari 2002

6. Notoatmodjo. Metodologi Penelitian - Pengertian Consecutive Sampling. Jakarta:CV Pustaka Setia; 2005 